\title{
EDITORIAL
}

\section{Manejo de plagas agricolas en el contexto de Zonas Aridas-Desérticas}

\author{
Management of agricultural pests in the contex \\ of Arid Desert Zones
}

\author{
Víctor Tello Mercado \\ Mg.Sc en Protección Vegetal \\ Dr. En ciencias silvoagropecuarias \\ Programa de Doctorado en \\ Agricultura para Ambientes \\ Áridos-Desérticos \\ Facultad de Recursos \\ Naturales Renovables \\ Universidad Arturo Prat
}

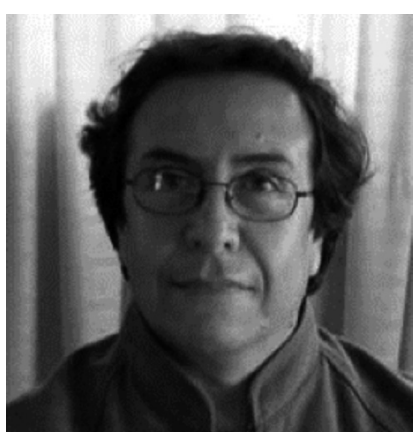

Victor Tello Mercado

M. Sc. in Plant Protection

Ph.D. in Agriculture and

Forestry Science

Doctoral Program in Agriculture

for Arid-desert Environments

Arturo Prat University
En Chile, de acuerdo a los últimos inventarios, existe un número aproximado de 617 especies de insectos y 49 de ácaros asociados con plantas cultivadas. De éstos, 385 y 24 especies, respectivamente, pueden ser consideradas como plagas de importancia económica. En el caso de las regiones más septentrionales de nuestro país (Arica y Parinacota y Tarapacá) encontramos aproximadamente 182 especies; 167 insectos $(91,8 \%)$ y 15 ácaros $(8,2 \%)$. Dentro de los insectos los órdenes mejor representados son: Lepidoptera (58 especies; 34,7\%), Hemiptera (57 especies; $34,1 \%$ ) y Coleoptera (35 especies; $21.0 \%$ ).

El manejo de plagas agrícolas, especialmente de insectos y ácaros fitófagos, independientemente del agro-ecosistema que se trate, es un problema de primer orden que debe resolverse para obtener rendimientos aceptables desde el punto de vista económico. Tradicionalmente el manejo de plagas se ha realizado a través de la aplicación de insecticidas sintéticos de amplio espectro los que sí bien han logrado menguar las poblaciones de las plagas también han causado graves problemas como contaminación de napas subterráneas y de suelos, impacto negativo sobre la fauna, efectos nocivos sobre la salud de aplicadores, contaminación de alimentos, entre otros. No menos graves ha sido el desarrollo de resistencia en las plagas y la resurgencia de otras por la eliminación de enemigos naturales.
According to the latest inventories there are approximately 617 insect species and 49 mites associated with cultivated plants in Chile. Of these, 385 and 24 species, respectively, may be considered as economically important pests. In the northernmost regions of Chile (Arica $y$ Parinacota, $y$ Tarapacá) there are about 182 species, 167 insects (91.8\%) and 15 mites (8.2\%). The most represented insect orders are the Lepidoptera (58 species; 34.7\%), Hemiptera (57 species; $34.1 \%$ ) and Coleoptera (35 species; $21.0 \%)$.

The management of agricultural pests, especially insects and phytophagous mites, is a first-order problem that must be resolved to obtain economically acceptable yields in any agro-ecosystem. Pest management has traditionally been performed by applying widespectrum synthetic insecticides. Although these have managed to reduce the populations of pests, they have also caused serious problems such as contamination of subterranean aquifers and soils, negative impacts on fauna, noxious effects on the health of the appliers and food contamination, among others. Not less important has been the development of resistance in pest species and the reappearance of others due to the elimination of their natural enemies. 
La agricultura en las zonas áridas-desérticas del norte de Chile se desarrolla en verdaderas "islas ecológicas", principalmente en agroecosistemas de oasis y valles (quebradas). Estos ecosistemas se caracterizan por estar rodeados de un desierto azoico el cual imposibilita la llegada a estos vergeles de enemigos naturales de las plagas, por lo que la eliminación de ellos en estos ecosistemas, por el mal uso de plaguicidas, es un fenómeno irreversible, por lo que su repoblamiento debe ser llevado a cabo en forma artificial, a través de crianza masiva y posterior liberación, acción conocida como control biológico.

Una condición característica de los ambientes áridos-desérticos es la baja humedad relativa y las temperaturas altas. A nivel de la Pampa del Tamarugal, la situación de desierto interior genera una condición de altas temperaturas diurnas las cuales descienden durante la noche, además de un invierno con temperaturas bajo cero. Diversas plagas que afectan a los bosques de Prosopis en este piso ecológico se han adaptado a través de mecanismos de quiescencia y diapausa que les permiten sortear los períodos en que no hay alimento para las larvas (botones florales y frutos incipientes), reapareciendo cuando comienza la floración en primavera. En cambio otras especies de fitófagos que utilizan como recurso alimenticio el follaje, pueden estar activos durante todo el año.

Una situación diferente se presenta en los oasis y en los valles, en los cuales las temperaturas invernales no suelen ser tan bajas ni tampoco se presenta una gran oscilación térmica durante el día. La presencia natural de fuentes de agua como "cochas" (vertientes) y ríos en los valles, sumado a la irrigación artificial genera microambientes con una alta humedad relativa que favorece la reproducción de las plagas. Estas condiciones agroclimáticas favorables sumado a la presencia de alimento durante todo el año (frutales perennes y cultivos) posibilitan que tanto insectos como ácaros fitófagos estén activos durante todo el año (multivoltinismo) y además que sus estadios se traslapen, es decir, en cualquier momento del año, será posible encontrar todos sus estados fenológicos (huevos, estados juveniles y adultos) al mismo tiempo.

Lo anterior tiene importantes implicancias en el manejo de plagas en zonas áridas-desérticas ya que no es posible encontrar una ventana biológica (estado más vulnerable) para aplicar alguna medida de control. También el monitoreo se complica ya que es impracticable utilizar técnicas de tiempo
Agriculture in the arid deserts of northern Chile occurs in true "ecological islands", mainly in agro-systems in oases and valleys. These ecosystems are surrounded by an azoic desert which makes it impossible for natural enemies of these pest species to arrive; their elimination by incorrect use of insecticides is an irreversible phenomenon. Thus their repopulation must be achieved artificially by raising and liberating large numbers of them, which is known as biological control.

Low relative humidity and high temperatures are characteristic of arid desert environments. The Pampa del Tamarugal is located in the interior desert where there is high diurnal fluctuation of temperature and temperatures below zero in winter. A number of the pests that affect the Prosopis forests there have adapted with mechanisms of quiescence and diapause that allow them to withstand the periods in which there is no food for their larvae (flower buds and unripe fruits), reappearing when flowering begins in spring, while other phytophagous species that feed on leaves may be active during the entire year.

A different situation occurs in the oases and the valleys, in which winter temperatures are not usually so low nor is the diurnal oscillation so large. The natural presence of water sources such as springs and rivers in the valleys, along with artificial irrigation generate microenvironments with high relative humidity that favors the reproduction of pests. These favorable climatic conditions added to the presence of food during the whole year (perennial fruit and crops) make it possible for both insects and phytophagous mites to be active during the entire year (multivoltine). Also, their stages overlap, thus at any moment of the year all their phenological stages (eggs, juveniles and adults) may be found.

This has important implications for plague management in arid desert zones, since there is no biological window (more vulnerable stage) to apply a control measure. Monitoring is also more complicated, since it is impractical to use techniques of physiological time (heat units or degree days) to determine a specific stage. It is possible to use absolute or trap-assisted sampling in s system of sequential monitoring to determine the precise moment to apply control measures, which is useful in these conditions. To achieve this 
fisiológico (unidades calor o grados días) para determinar un estadío específico. Muestreos de tipo absoluto o asistidos con trampas (cromoatrayentes, feromonas o fototrópicas) es posible utilizarlos dentro de un sistema de muestreo secuencial para determinar el momento preciso de aplicación de control, son útiles para estas condiciones. Para lograr lo anterior es necesario determinar los umbrales de acción de cada una de las plagas, labor que sólo se ha realizado sólo para algunas de ellas.

Por último, los productos insecticidas/acaricidas a aplicar en ambientes áridos-desérticos deben ser ecológicamente adecuados (biorracionales) debido al delicado equilibrio existente entre plagas y enemigos naturales. Extractos y/o aceites vegetales extraídos desde plantas endémicas, nativas o locales han sido evaluadas con éxito. Organismos entomopatógenos, aplicados a nivel de campo, han resultado ser promisorios en el control de plagas. La baja humedad relativa ha sido un problema pero se ha resuelto en la formulación de estos bioplaguicidas con la adición de gomas, aditivos proteicos y utilizando una emulsión de tipo invertida. El uso de entomófagos (parasitoides y depredadores) ha sido aplicado desde hace varias décadas en el norte de Chile, a nivel de oasis (i.e. Cales noacki contra mosquita blanca en cítricos de Pica), a nivel de Pampa del Tamarugal (i.e. Trichogramma contra plagas de lepidópteros en Prosopis en la Reserva Nacional Pampa del Tamarugal), a nivel de valles (i.e. Trichogramma contra Tuta absoluta en tomate cultivado en Azapa). El control biológico como herramienta dentro del manejo integrado de plagas es la alternativa más adecuada en los ambientes áridos-desérticos del norte de Chile, para mantener las poblaciones de las plagas a un nivel que no produzcan perjuicios económicos. it is necessary to dominate the action thresholds of each of the pest species, which so far are known for only a few of them.

Finally, the insecticides/acaricides must be adequate to apply in arid desert environments (bio-rational), due to the delicate equilibrium existing between pests and their natural enemies. Extracts or oils from endemic, native and local plants have been evaluated successfully. Insect pathogens applied in the field have proved promising in pest control. The low relative humidity problem has been solved in the formation of these bio-pesticides by the addition of gums and protein additives, and by using inverted emulsions. Parasitoids and predators have been used for a number of decades in northern Chile, in oases (i.e. Cales noacki against white flies in citrus orchards in Pica), in the Pampa del Tamarugal (i.e. Trichogramma against butterfly plagues in Prosopis in the Reserva Nacional Pampa del Tamarugal, and in valleys (i.e. Trichogramma against Tuta absoluta in tomato crops in Azapa. Biological control as a tool in integrated pest management is the most adequate alternative in the arid desert environments of northern Chile to maintain pest populations at a level that they do not produce economic prejudice. 
